\title{
Population Briefs, Vol. 12, no. 3
}

Population Council

Follow this and additional works at: https://knowledgecommons.popcouncil.org/ series_newsletters_popbriefs How does access to this work benefit you? Let us know!

\section{Recommended Citation}

Population Briefs 12(3): New York: Population Council, 2006. 


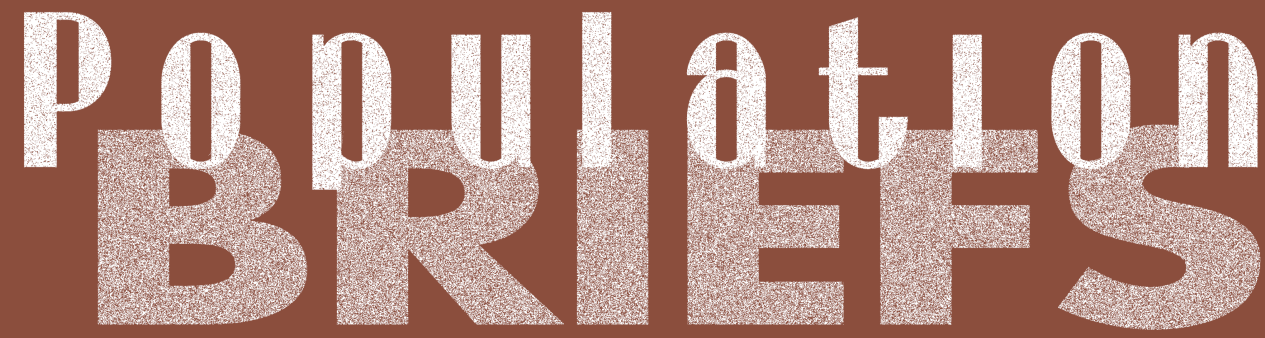

Reports on Population Council Research

\section{Council Study Clarifies Status of Vulnerable Populations After Pakistan Earthquake}

On the morning of 8 October 2005, an earthquake registering a minimum magnitude of 7.6 struck Pakistan's North West Frontier Province and Azad Jammu and Kashmir. The earthquake left devastation, with more than 73,000 dead and 100,000 injured. Many of the more than 3 million people who were displaced or homeless were moved to tent camps set up by the government and relief agencies. Others moved to tents erected wherever homes were uninhabitable. The earthquake occurred just before the start of winter snowfall, which threatened a second round of disaster if effective aid did not reach people quickly. In order to develop a viable rehabilitation plan and to provide such aid, the Pakistan government and relief agencies needed accurate data on the refugees housed in tent camps.

Like many people in the regions surrounding the earthquake, Population Council staff members in Pakistan sought to do what they could to provide relief to people affected by the disaster. They started a fund to which employees could contribute; gathered donations of food, clothing, and other necessities; and held weekly meetings to discuss the situation.

"But we thought we could do more and really use our skills as researchers to help," says Zeba Sathar, country director for the Population Council in Pakistan. "We attended government meetings and quickly found that until that point, assessments of the populations in the tent camps had not been conducted with scientific rigor. The data—particularly for the most vulnerable people: orphans, wid- ows, people with disabilities, and the elderlywere inadequate."

The Population Council was asked by the United Nations to gather data on the people living in tent camps. (Other people affected by the earthquake were in hospitals or living with

$$
\begin{aligned}
& \text { "Most of the fieldwork } \\
& \text { was undertaken in rain } \\
& \text { and snowfall, and we } \\
& \text { completed the assign- } \\
& \text { ment in } 28 \text { days." }
\end{aligned}
$$

family or friends.) The Council collaborated with the Pakistan Ministry of Social Welfare and Special Education, the United Nations Population Fund, and the United Nations Children's Fund to complete this study. Council researcher Arshad Mahmood led the team. The main objective was to locate and assess the size and needs of the most vulnerable populations. Because time was short, the survey was completed quickly. The fieldwork began 4 January 2006, in harsh terrain and weather conditions. The Council collected information from every individual living in camps that contained ten or more tents. Data were collected on more than 45,000 families and 250,000 individuals.
"On the very first day our teams in Azad Jammu and Kashmir could not start their fieldwork because of the heavy rain," says Mahmood. "The next day, we provided them umbrellas and raincoats, and they went to the field for data collection by walking more than three hours in some cases. Our teams also used helicopters, courtesy of the Pakistan Army, to reach the top of the mountains to collect data. Most of the fieldwork was undertaken in rain and snowfall, and we completed the assignment in 28 days. We presented the results within 45 days."

\section{Findings on vulnerable groups}

Children, in particular those who lost one or both parents, have been made especially vulnerable by the earthquake. Children are exposed to exploitation, abuse, and child labor. The assessment found that more than 10 percent of children, those younger than 18 , in the camps were orphans, though not necessarily because of the earthquake. Nearly 4 percent of children lost one or both parents in the earthquake. The analysis showed that out of every 1,000 children living in the camps, 39 lost one or both of their parents during the earthquake. Out of these, 20 lost their mothers, 17 lost their fathers, and 2 lost both parents. (See graph.)

The results also showed that 1.6 percent of males and 2 percent of females in the camps were disabled by the earthquake. "Severe and multiple injuries" were the most 


\section{Partner-Delivered Therapy Viable in Resource-Poor Areas}

In South Africa and Brazil, the Population Council has recently studied alternative methods of notifying partners of women with sexually transmitted infections (STIs) that they need treatment. These studies have verified that offering women with STIs the option of bringing medicines to their partners, rather than requiring partners to come to the clinic, results in high treatment rates.

\section{Notifying partners of infection}

Notifying people that their sexual partners have an STI is an important means of reducing the transmission of infection. The practice of partner-delivered medicine has been shown to increase the number of partners contacted and to decrease the rate of re-infection in resource-rich settings, but little work has been done to demonstrate its effectiveness in resource-poor settings. It is in these places, however, where the strategy might be most useful; partner notification methods that rely upon outreach by health professionals are difficult to maintain in resource-poor settings, which often have shortages of providers.

Population Council researchers Heidi E.

Jones, Juan Diaz, and Sheri A. Lippman collaborated with colleagues from Santa Casa Medical School and the University of Cape Town to study partner-delivered treatment programs in São Paulo, Brazil and Gugulethu, Cape Town, South Africa. These investigations were part of two larger studies of home-based STI testing. The studies tested for the presence of trichomoniasis, chlamydia, and gonorrhea among participating women. These infections may increase the risk of HIV infection and contribute to infertility, pelvic inflammatory disease, obstetric complications, and illness in newborns. Further, they can all be treated with a single dose of medication.

\section{São Paulo}

In Brazil, women who had trichomoniasis were offered three options for partner notification: notifying their partners themselves, having a health professional notify their partners, or bringing medication and instructions on use to their partners. Women with chlamydia or gonorrhea were offered only the first two options because study clinicians felt that direct counseling of the partners was a priority. Of the 787 women in the larger study, 108 had at least one of the three infections.

\section{"We need to reach out}

to providers and

educate them about the

$$
\text { benefits of this strategy." }
$$

Twenty-eight women had trichomoniasis. Four of them reported no sexual partners in the last three months, so partner notification was not conducted. Eighty-one percent of the partners of the remaining women were treated, 91 percent receiving partner-delivered medicine.

Eighty-five women had gonorrhea and/or chlamydia, four of whom reported having no sex partners in the last three months. Fortyfour percent of the partners of the remaining women came to the clinic for treatment, and 31 percent received partner-delivered medication. Although the latter option was offered initially only to women with trichomoniasis, providers later began offering this option to women with other infections whose partners did not come to the clinic. The majority of partners who were not treated were those of patients who refused to contact the partner, usually because they were no longer a couple.

\section{Gugulethu}

In South Africa, all women who were found to have any of these three infections were given a choice between bringing clinic referral slips to their partners or bringing medicine and instructions on use to their partners. Of the 626 women in the larger study, 106 were found to have at least one STI. The women chose to take medication to 85 percent of their partners and a referral slip to 13 percent of their partners. The most common reason women elected to get the medication was their concern that their partners might initially agree to visit a clinic, but would not follow through. The second most common reason given was that a woman's partner was too busy to attend a clinic or would refuse to attend for other reasons.

"The high rates of STIs we found in these studies confirm the urgent need for improved methods of preventing disease transmission," says Jones. "Patient-delivered medicine was the preferred method of partner notification in both studies, and it resulted in high rates of partner treatment."

A barrier to partner notification in general is the lack of highly accurate and inexpensive STI diagnostic tests in resource-poor settings, say the researchers. Additionally, says Diaz, "we need to reach out to providers and educate them about the benefits of this strategy. In the Brazil study, and in studies in other countries, physicians have expressed reservations about using partner-delivered medication. Their understanding and approval are crucial to the method's success."

\footnotetext{
SOURCES

Young, T., A. de Kock, H. Jones, L. Altini, T. Ferguson, and J.H.H.M. van de Wijgert. "A comparison of two methods of partner notification for sexually transmitted infections in South Africa: Patient-delivered partner medication and patient-based partner referral," forthcoming in International Journal of STD \& AIDS. Jones, Heidi E., Sheri A. Lippman, Adriana A. Pinho, Carla Gianni Luppi, Janneke H.H.M. van de Wijgert, and Juan Diaz. 2006. "Partner-delivered medication for sexually transmitted infections: Findings from Brazil," Gaceta Médica de México 142(S2): 69-76.

U.S. Agency for International Development
} 


\section{Illuminating the Status of Mayan Girls in Guatemala}

Guatemala's population is among the poorest, least educated, youngest, and fastest growing in Latin America. Indigenous (Mayan) girls are among the most disadvantaged, vulnerable members of the population. The Population Council has conducted research to better understand the status of Mayan girls. The results of these studies have been used to design programs to improve Mayan girls' lives and health and to address the educational inequities they face.

\section{Education}

The Population Council team was led by development economist Kelly Hallman and included former Council Berelson Fellow Sara Peracca and researchers Jennifer Catino and Marta Julia Ruiz. They examined data from the 2000 Guatemala Living Standards Measurement Survey (in Spanish Encuesta Nacional sobre Condiciones de Vida, or ENCOVI). Data for this survey were collected between 1999 and 2000 from a nationally representative sample of 11,170 households: 3,544 urban and 7,626 rural. The researchers focused on education among 7-24-year-olds. (Seven is the age at which school enrollment is compulsory in Guatemala, and most people are no longer enrolled by the time they reach 24.) They compared Mayan females to Mayan males and nonindigenous (known as Ladino) males and females.

They found that at each year of age, Mayan girls are less likely than other children to be enrolled in school. At age seven, only 54 percent of Mayan girls are in school, compared with 71 percent of Mayan boys and around three-quarters of Ladino boys and girls. At age 16, only 25 percent of Mayan girls are enrolled, versus around half of Mayan boys and Ladino girls and boys.

The one-quarter of Mayan girls who are classified as extremely poor have the worst educational outcomes: only half of such girls between 7 and 12 years old have entered school, fewer than 10 percent of girls 13-24 years of age who entered primary school have completed that level, and just 14 percent of these primary school graduates have ever enrolled in secondary school. Mayan girls from extremely poor households who ever enrolled in school did so much later than other children: 0.73 years later than Mayan girls in medium poor households and 1.2 years later than Mayan girls in nonpoor households.

For primary-age children (7-12 years) in every gender-ethnicity status who were not enrolled at the time of the survey, lack of money was the largest single factor identified for nonenrollment. Lack of interest in school was the second most frequently cited reason, followed by "age" - presumably being overage for grade.

Among 13-24-year-olds, the most frequently cited reasons for not being enrolled in school were household chores (for females) and work (for males). Among both sexes, lack of money was the second most common reason, with few differences by ethnicity. "Mayan girls have by far the lowest primary school completion rates, due in large part to povertydriven domestic labor burdens that begin to impinge upon them at puberty," says Hallman.

\section{Early marriage and childbearing?}

At first glance, it might seem as if early marriage and childbearing are not inhibiting Mayan girls' education. There is a time lag of several years between the mean age at leaving school and the mean age at marriage for Mayan girls. There is also very little out-of-wedlock childbearing in Guatemala. However, the Council's qualitative work in Mayan communities suggests that plans for marriage and childbearing do play an indirect role in early school dropout. Parents said they were reluctant to invest in daughters' education beyond the age of puberty for economic and safety reasons and because most expected their daughters to become wives and mothers - roles for which advanced education was not viewed as necessary.

"Our analysis shows that enrollment rates of all young people drop drastically at age
12 years, but the effect is the most pronounced for Mayan girls. Among nonenrolled Mayan girls age $12-18$, only about 10 percent have completed primary school, indicating that obstacles in progressing from primary to secondary school are not the main reason for Mayan adolescent girls' nonenrollment. Our research reveals that poverty and pressure to undertake unpaid household chores are the main reasons," says Hallman. These findings point to the need to better target scholarships and other educational incentive programs, in addition to continuing to extend the reach of poverty-reduction programs.

\section{A program to belp}

In response to these findings, Council researchers designed and implemented an innovative pilot intervention in collaboration with FESIRGUA (the Guatemalan Federation of Reproductive and Child Health), a well-established multisectoral network of Mayan nongovernmental organizations. The project is designed to improve Mayan girls' health, education, and life circumstances. Young Mayan women aged 17-20 receive livelihoods and entrepreneurial training as well as information about reproductive and general health. They then spend half their time in the project working in an office setting with professional adult mentors. They spend the other half of their time serving as role models and teaching the curriculum to younger girls aged 12-15, and interacting with these girls' mothers and other important community stakeholders. Results from this intervention will be available in 2007 .

\section{SOURCE}

Hallman, Kelly, Sara Peracca, Jennifer Catino, and Marta Julia Ruiz. 2006. "Multiple disadvantages of Mayan females: The effects of gender, ethnicity, poverty, and residence on education in Guatemala," Policy Research Division Working Paper no. 211. New York: Population Council.

\section{OUTSIDE FUNDING}

U.K. Department for International Development, the Center for Global Development, the Bill and Melinda Gates Foundation, the William and Flora Hewlett Foundation, and the Andrew W. Mellon Foundation 


\section{CDB-2914 May Be an Effective Fibroid Treatment}

Between 20 and 40 percent of women older than 35 have uterine fibroids. Also known as leiomyomas, uterine fibroids are benign (noncancerous) tumors in the muscular wall of the uterus. They can range from the size of a grape to the size of a cantaloupe. Although otherwise benign, fibroids may cause heavy menstrual flow and pain in some women. The discomfort and bleeding associated with fibroids lead many women with the condition to have hysterectomies, or surgical removal of the uterus. As many as one-quarter to one-half of the 600,000 hysterectomies performed annually in the United States are performed to treat fibroids.

Studies of the drug CDB-2914 suggest that it may be an effective treatment for fibroids. It is possible that CDB-2914 could be delivered into the body via a vaginal ring or intrauterine system. These studies were conducted by obstetrician/gynecologist Takeshi Maruo and his team at Japan's Kobe University, in collaboration with two Council biomedical scientists: reproductive endocrinologist Régine L. Sitruk-Ware and obstetrician/ gynecologist Elof D.B. Johansson. Sitruk-Ware is executive director of product research and development at the Council's Center for Biomedical Research, and Johansson is a Population Council vice president, responsible for the center. Maruo is a member of the Council's International Committee for Contraception Research (ICCR). The Population Council and its ICCR are also studying CDB2914 for use as a potential contraceptive.

\section{Progesterone receptor modulator}

Several lines of research suggest that the female hormone progesterone plays a role in the growth of fibroids. Progesterone exerts its influence by binding with molecules, known as progesterone receptors, in cells. When progesterone binds with the progesterone receptor, it activates the receptor. The activated receptor determines when specific genes will turn on. When a gene turns on, it produces the proteins that tell the cell what to do.
CDB-2914 is a member of a class of drugs known as progesterone receptor modulators, which also bind to the progesterone receptor, preventing progesterone from binding with it. When progesterone cannot bind to the receptor, the genes with which it interacts remain inactive.

Maruo and his team performed in vitro culture studies mixing CDB-2914 with cells from uterine fibroids and with cells from normal uterine smooth muscle. The scientists measured the levels of various proteins and looked for growth (or lack of growth) in those cultured cells. The tissues were taken from

\section{"These results suggest}

that $C D B-2914$ may

inbibit the growth of

uterine fibroids,

while not affecting the

surrounding bealthy

smooth muscle."

women with normal menstrual cycles who underwent fibroid removal or hysterectomy. All the women were being treated for fibroids at Kobe University Hospital.

\section{Apoptosis and angiogenesis}

The researchers looked at levels of proteins associated with two processes - apoptosis and angiogenesis - that influence the growth of tumors. Apoptosis is genetically programmed cell death. Unlike cell death caused by disease, however, apoptosis is normal, orderly, and generally not harmful. Angiogenesis is the growth of new blood vessels. This process is essential to wound healing, but also to the growth of fibroids and other tumors.

The researchers found fewer fibroid cells in cultures treated with CDB-2914 than in untreated cultures. They also found that fibroid-cell cultures treated with CDB-2914 had lower concentrations of two proteins: proliferating cell nuclear antigen (PCNA) and Bcl-2. If present at higher levels, PCNA and Bcl-2 would induce fibroid growth by stimulating cell proliferation and by inhibiting apoptosis, respectively. The researchers found that in fibroid cells, but not in cells from normal uterine smooth muscle, CDB-2914 reduces levels of proteins that stimulate angiogenesis: adrenomedullin and vascular endothelial growth factor. Conversely, CDB-2914 increases the amount of two proteins that trigger apoptosis: cleaved caspase-3 and cleaved poly(ADPribose) polymerase.

"These results," says Maruo, "suggest that CDB-2914 may inhibit the growth of uterine fibroids, while not affecting the surrounding healthy smooth muscle. These findings contribute additional evidence that CDB-2914 may be useful in the treatment of uterine fibroids."

\section{SOURCES}

Xu, Qin, Shigeki Takekida, Noriyuki Ohara, Wei Chen, Régine Sitruk-Ware, Elof D.B. Johansson, and Takeshi Maruo. 2005. "Progesterone receptor modulator CDB-2914 down-regulates proliferative cell nuclear antigen and $\mathrm{Bcl}-2$ protein expression and up-regulates caspase-3 and poly(adenosine 5'-diphosphateribose) polymerase expression in cultured human uterine leiomyoma cells," Journal of Clinical Endocrinology \& Metabolism 90(2): 953-961.

Xu, Qin, Noriyuki Ohara, Wei Chen, Jin Liu, Hiroko Sasaki, Akira Morikawa, Régine Sitruk-Ware, Elof D.B. Johansson, and Takeshi Maruo. 2006. "Progesterone receptor modulator CDB-2914 down-regulates vascular endothelial growth factor, adrenomedullin and their receptors and modulates progesterone receptor content in cultured human uterine leiomyoma cells," Human Reproduction 21(9): 2408-2416.

\section{OUTSIDE FUNDING}

HRA Pharma (Paris, France), Japanese Ministry of Education, Science and Culture, and the Ogyaa-

Donation Foundation of the Japan Association of Obstetricians and Gynecologists 
continued from page 1

common disabilities reported. The highest proportion of disabilities was found among people in their productive years - between 19 and 59 years old — and among the elderly. Nearly 2 percent of young men and nearly 3 percent of young women reported disabilities. More than 4 percent of elderly women and men were disabled. Just over 1 percent of boys and girls reported disabilities. The researchers concluded that "special measures need to be taken to address the needs of children who may be permanently disabled due to their injuries. Long-term care and rehabilitation will be required, as well as help with the development of skills and training for employment."

Disasters such as this can have a disproportionate negative effect on the elderly. Older people find it harder to access relief goods and shelters and need special attention, as well as physical and emotional support in the relief camps. The vulnerable elderly are primarily affected when they have suffered injuries and disability or when they have lost family support. Out of 11,540 elderly people in camps, 1,564 were without any adult support.

Women in the camps face a high risk of sexual exploitation, violence, trafficking, and physical abuse. In the aftermath of the earthquake, women found it harder than men to find employment and to access the relief goods. Widows and members of female-headed households need outside support to help them establish appropriate living arrangements and sources of livelihood within the community. The camp survey registered 768 women as having lost their husbands as a result of the earthquake and 4,620 women as widowed before the earthquake. Female-headed households made up almost 10 percent of households in the camps.

The survey also showed that there were 2,778 pregnant women in the camps who needed proper nutritional and antenatal care. Pregnancy and delivery can be dangerous for women in the best of circumstances. Because of the earthquake, however, women are at greater risk since they generally cannot get prenatal or emergency obstetric care. Skilled birth attendants, for example, were present at

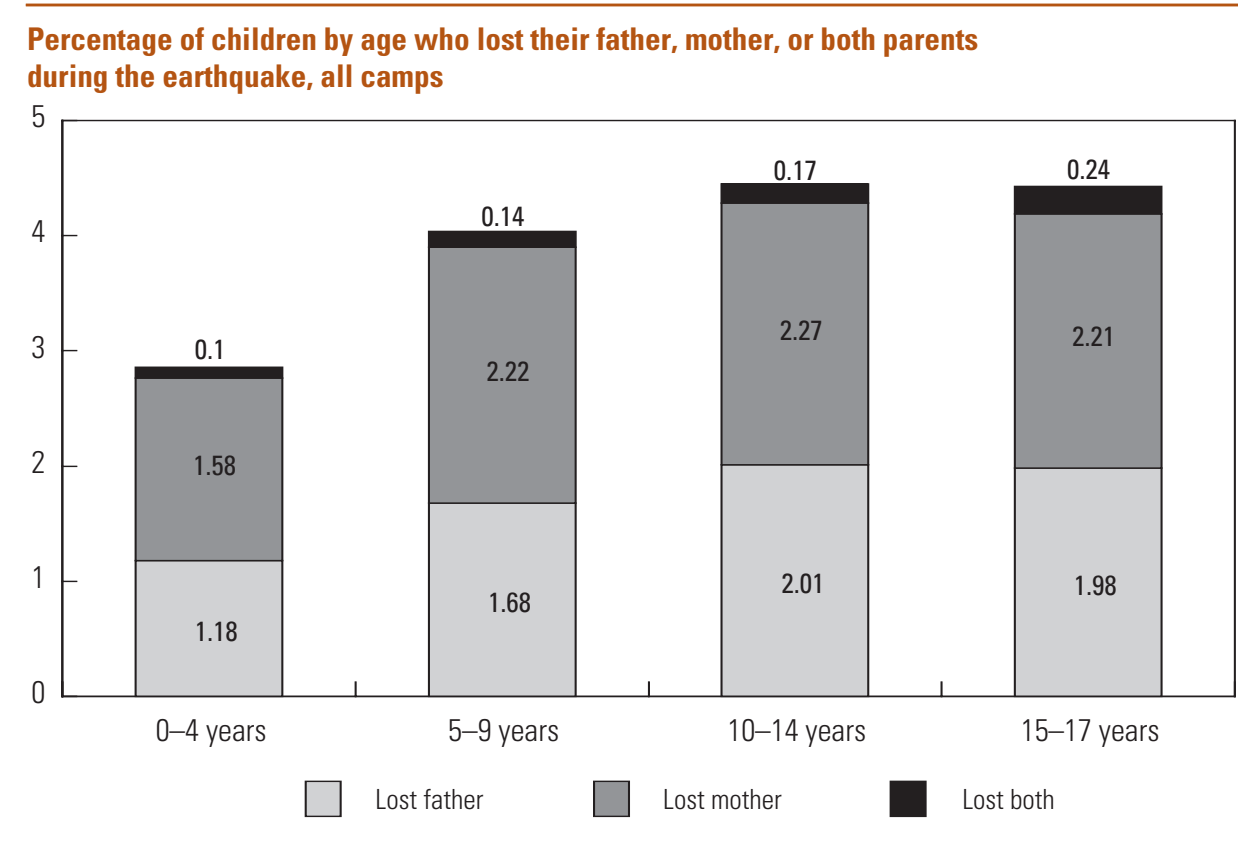

only one-third of camp deliveries. Further, only 59 percent of the babies born in the camps after the earthquake were vaccinated. Lack of access to appropriate medical care may not be the only cause of poor pregnancy outcomes. Disasters like the earthquake can have indirect consequences as well. During such periods, spontaneous abortions (miscarriages) can increase sharply owing to physical and mental stress, and women who suffer miscarriages require emergency assistance to save their lives and protect their fertility.

The survey also assessed the willingness of displaced families to leave the camps and return to their communities. More than onequarter reported that they were not prepared to go back. Just under a quarter were already residing in camps in their home communities. Less than 3 percent of families said they wanted to go back as soon as possible, 13 percent wanted to go back within two months, and one-quarter said they wanted to go back within four months.

\section{Outcomes}

The findings of this assessment of vulnerable populations have been used by the government of Pakistan in developing its rehabilitation plan. The complete database has been given to the government's National Commission for Child Welfare and Development, a division of the Ministry of Social Welfare and Special Education. Population Council researchers are training ministry staff members in the use of the database. Ministry staff will use the database to keep track of the rehabilitation of displaced populations. The survey has provided baseline information to the government and aid agencies, and the data have helped in the development of more focused and efficient rehabilitation plans that address the diverse needs of people affected by the earthquake.

"Most of the Population Council employees who worked on the survey worked day and night to complete this very important task on a voluntary basis, in spite of their other work commitments," says Mahmood. "All of them are proud of having contributed to efforts to reduce the dreadful outcomes of the terrible national tragedy."

\section{SOURCE}

Mahmood, Arshad. 2006. "Earthquake vulnerability assessment-Pakistan, 2005-06," Islamabad: Population Council.

\section{OUTSIDE FUNDING}

United Nations Children's Fund and United Nations Population Fund 


\section{RECENT PUBLICATIONS}

\section{Biomedicine}

Deshpande, Shayu, Matthew P. Hardy, and A. J. Rao. "Delineating the role of estrogen in regulating epididymal gene expression," in S. K. Gupta and K. Koyama (eds.), Gamete Biology, Society of Reproduction and Fertility. United Kingdom: Nottingham University Press.

Duclayan, Gina. "Day of dialogue on public sector pricing of pharmaceutical products," report of a meeting. New York: Population Council.

Rad, Mandana, Cornelius Kluft, Joël Menard, Jacobus Burggraaf, Marieke L. de Kam, Piet Meijer, Irving Sivin, and Régine Sitruk-Ware. "Comparative effects of a contraceptive vaginal ring delivering a nonandrogenic progestin and continuous ethinyl estradiol and a combined oral contraceptive containing levonorgestrel on hemostasis variables," American Journal of Obstetrics and Gynecology 195(1): 72-77.

Sitruk-Ware, Régine. “The levonorgestrel-releasing intrauterine system (Mirena ${ }^{\circledR}$ )," Gynaecology Forum 11(2).

Skoler, Stephanie, Leigh Peterson, and Ward Cates "Our current microbicide trials: Lessons learned and to be learned," The Microbicide Quarterly 4(1): $1-6$.

Spitz, Irving M., Steven M. Grunberg, Nathalie Chabbert-Buffet, Tzina Lindenberg, Hadassa Gelber, and Régine Sitruk-Ware. "Management of patients receiving long-term treatment with mifepristone," Fertility and Sterility 84(6): 1719-1726.

Teleshova, Natalia, Jessica Kenney, and Melissa P. Robbiani. "Dendritic cells and HIV infection: Activating dendritic cells to boost immunity," Advances in Dental Research 19: 36-41.

Vigodner, Margarita, Tomomoto Ishikawa, Peter N. Schlegel, and Patricia L. Morris. "SUMO-1, human male germ cell development and the androgen receptor in the testis of men with normal and abnormal spermatogenesis," American Journal of Physiology: Endocrinology and Metabolism (Translational Series) 290(5): E1022-E1033.

\section{Gender and Family Dynamics}

García-Moreno, Claudia and Rachel Goldberg. "Living up to their name: Profamilia takes on gender-based violence," Quality/Calidad/Qualité no. 18. New York: Population Council.

Khan, M. E. and Aditi Aeron. "Prevalence, nature and determinants of violence against women in Bangladesh," Journal of Family Welfare 52(special issue).

Ruel, Marie T., Agnes Quisumbing, Kelly Hallman, Bénédicte de la Brière, and Nora Coj de Salazar. “The Guatemala Community Day Care Program: An example of effective urban programming," IFPRI Research Report no. 144. Washington, DC: International Food Policy Research Institute.

\section{HIV/AIDS}

Denison, Julie. "Social relationships and adolescents' HIV counseling and testing decisions in Zambia," Horizons Research Summary. Washington, DC: Population Council.

Duraisamy, P., A. K. Ganesh, Rick Homan, N. Kumarasamy, Chris Castle, P. Sripriya, Vaishali Sharma Mahendra, and S. Solomon. “Costs and financial burden of care and support services to PLHA and households in South India," AIDS Care 18(2): 121-127.

"HIV service delivery," The Horizons Report, June. Washington, DC: Population Council.

Horizons Program. "Strengthening care and support services in the era of treatment: Symposium report, 22-23 November 2005, Johannesburg, South Africa," Washington, DC: Population Council.

Mahendra, Vaishali Sharma, Laelia Gilborn, Bitra George, Luke Samson, Rupa Mudoi, Sarita Jadav, Indrani Gupta, Shalini Bharat, and Celine Daly. "Reducing stigma and discrimination in hospitals: Positive findings from India," Horizons Research Summary. Washington, DC: Population Council.

Michaels, Desireé, Brian Eley, Lewis Ndhlovu, and Naomi Rutenberg. “Exploring current practices in pediatric ARV rollout and integration with early childhood programs in South Africa: A rapid situation analysis," Washington, DC: Population Council.

Onyango-Ouma, W., Harriet Birungi, and Scott Geibel. "Understanding the HIV/STI prevention needs of men who have sex with men in Kenya," Horizons Research Summary. Washington, DC: Population Council.

Orner, Phyllis, Jane Harries, Diane Cooper, Jennifer Moodley, Margaret Hoffman, Julie Becker, Elizabeth McGrory, Rasha Dabash, and Hillary Bracken. "Challenges to microbicide introduction in South Africa," Social Science \& Medicine 63(4): 968-978.

Pulerwitz, Julie, Gary Barker, Márcio Segundo, and Marcos Nascimento. "Promoting gender equity among young Brazilian men as an HIV/AIDS prevention strategy," Horizons Research Summary. Washington, DC: Population Council.

Pulerwitz, Julie, Tiffany Lillie, Louis Apicella, Ann McCauley, Tobey Nelson, Simon Ochieng, Peter Mwarogo, Karusa Kiragu, and Edward Kunyanga. "ABCs for HIV prevention in Kenya: Messages, beliefs, and barriers," Horizons Research Summary. Washington, DC: Population Council.

"ABC messages for HIV prevention in Kenya: Clarity and confusion, barriers and facilitators," Washington, DC: Population Council.

Samuels, Fiona, Ravi K. Verma, and C. K. George. "Reducing HIV risk behaviors among key populations by increasing community involvement and building social capital: Baseline findings from Andhra Pradesh, India," Horizons Research Update. New Delhi: Population Council.

Thurman, Tonya, Leslie Snider, Neil Boris, Edward Kalisa, Eleazer N. Mugarira, Joseph Ntaganira, and
Lisanne Brown. "Psychosocial support and marginalization of youth-headed households in Rwanda," AIDS Care 18(3): 220-229.

van de Wijgert, Janneke and Heidi Jones. "Challenges in microbicide trial design and implementation," Studies in Family Planning 37(2): 123-129.

Verma, Ravi K., Vaishali Sharma Mahendra, Pertti J. Pelto, Sarat C. Pradhan, and Vibha Singh. "Context and dynamics of male-to-male sexual behavior of truckers in India: Findings from a multi-site qualitative research study," Research Brief. New Delhi: Population Council.

\section{Quality of Care}

Birungi, Harriet and W. Onyango-Ouma.

"Acceptability and sustainability of the focused antenatal care package in Kenya," FRONTIERS Final Report. Washington, DC: Population Council.

Bruce, Egbert, Daniel Mensah, John Idun, Francis Ashabley, James Foreit, and Philomena Nyarko. "Face-to-face complementary selling of health products in Ghana," FRONTIERS Final Report. Washington, DC: Population Council.

Nyarko, Philomena, Harriet Birungi, Margaret Armar-Klemesu, Daniel Arhinful, Sylvia Deganus, Henrietta Odoi-Agyarko, and Gladys Brew.

"Acceptability and feasibility of introducing the WHO focused antenatal care package in Ghana," FRONTIERS Final Report. Washington, DC: Population Council.

Varkey, Leila, M. E. Khan, Vivek Sharma, and Dinesh Aggarwal. "District quality assurance programme for reproductive health services: An operational manual," Washington, DC: Population Council.

\section{Reproductive Health}

"Adolescent reproductive health: Resources from Africa," CD-ROM. Nairobi, Population Council.

Birungi, Harriet, Philomena Nyarko, lan Askew, Ayorinde Ajayi, Gifty Addico, Edward Addai, and Caroline Jehu-Appiah. "Priority setting for reproductive health at the district level in the context of health sector reforms in Ghana," FRONTIERS Final Report. Washington, DC: Population Council.

Cravero, Kathleen, Michelle Skaer, Victoria Ebin, and Martha Brady. "In our own hands: SWAAGhana champions the female condom,"

Quality/Calidad/Qualité no. 17. New York: Population Council.

"Emergency contraception: A method every woman should know," Washington, DC: Population Council.

"Female genital cutting: Publications on research in FGC," CD-ROM. Washington, DC, Population Council.

"Improving reproductive health services: FRONTIERS operations research 1998-2005," CD-ROM. Washington, DC: Population Council.

Janowitz, Barbara and James Foreit. “Public sector family planning: How can we pay for it?" USAID

Publications are by Population Council staff members, consultants, or staff from partner organizations. Year of publication is 2006 unless otherwise noted. Names in boldface are staff 
Maximizing Access and Quality (MAQ) Technical Brief. Washington, DC: The INFO Project.

Joyce, Stephanie. "Accelerating the abandonment of female genital cutting: Community change to support human rights," USAID Maximizing Access and Quality (MAQ) Technical Brief. Washington, DC: The INFO Project.

Nidadavolu, Vijaya and Hillary Bracken. "Abortion and sex determination: Conflicting messages in information materials in a district of Rajasthan, India," Reproductive Health Matters 14(27): 160-171.

Rahman, Laila and Ismat Bhuiya. "Training manual for trainers on life skill based RH, HIV/AIDS, and gender education for adolescents and youths," Dhaka: Population Council.

RamaRao, Saumya, John Townsend, and lan Askew. "Correlates of inter-birth intervals: Implications of optimal birth spacing strategies in Mozambique," FRONTIERS Final Report. Washington, DC: Population Council.

“SMART Dai: A training package for traditional birth attendants in Pakistan." Islamabad, Population Council.

"Strengthening financial sustainability through integration of voluntary confidential counseling testing services with reproductive health services," Asia and Near East OR Summary no. 13. Washington, DC: Population Council.

"We shall get aware: Life skill based reproductive health, HIV/AIDS and gender education for adolescents and youths," Student manual. Dhaka: Population Council.

\section{Social Science}

Arshad, Mahmood. "Earthquake vulnerability assessment Pakistan, 2005-06," Islamabad: Population Council.

Demeny, Paul and Geoffrey McNicoll. "The political demography of the world system, 2000-2050," in Paul Demeny and Geoffrey McNicoll (eds.), The Political Economy of Global Population Change, 1950-2050, Supplement to Population and Development Review, Vol. 32. New York: Population Council, pp. 254-287.

. "World population 1950-2000: Perception and response," in Paul Demeny and Geoffrey McNicoll (eds.), The Political Economy of Global Population Change, 1950-2050, Supplement to Population and Development Review, Vol. 32. New York: Population Council, pp. 1-51.

(eds.). The Political Economy of Global

Population Change, 1950-2050, Supplement to Population and Development Review, Vol. 32. New York: Population Council.

McNicoll, Geoffrey. "Review of William Easterly, The White Man's Burden: Why the West's Efforts to Aid the Rest Have Done So Much III and So Little Good," Population and Development Review 32(2): 376-378.
Rob, Ubaidur, M. M. Islam, Md. Mahabub-ul-Anwar Aminul Arifeen, Md. N. Talukder, and Laila Rahman. "Population and development: Pilot research at community level on linkage between reproductive health and poverty," Dhaka: Population Council and UNFPA.

"Slow fertility transitions in Egypt: Key findings and recommendations," Cairo: Population Council.

Zimmer, Zachary, John Knodel, Kiry Sovan Kim, and Sina Puch. "The impact of past conflicts and social disruption on the elderly in Cambodia," Population and Development Review 32(2): 333-360.

\section{Stengthening Local Resources}

Birungi, Harriet, Nzoya Munguti, Moses Mokua, and Rick Homan. "Cost analysis of reproductive heath services in PCEA Chogoria Hospital, Kenya," FRONTIERS Final Report. Washington, DC: Population Council.

Boateng, James, Henry Surnye, Alex Mensah, Bismark Boateng, Philomena Nyarko, Nzoya Munguti, and John Bratt. "Costs of reproductive health services provided by four CHAG hospitals," FRONTIERS Final Report. Washington, DC: Population Council.

"Enhancing cost recovery through afternoon clinic: Findings from an operations research study in Nepal," Asia and Near East OR Summary no. 14. Washington, DC: Population Council.

Khan, M. E., Sohini Roychowdhury, Jim Foreit, Sharif Mohammed Ismail Hossain, and Geetha Vaithyanathan. "Developing regional capacity in operations research and economic evaluation in South Asia," FRONTIERS Final Report. Washington, DC: Population Council.

Merida, Martha, Javier Arce, Douglas Moscoso, Carlo Ramirez, Patricia Riveros, and John Bratt. "Operations research to improve financial sustainability in three Bolivian NGOs," FRONTIERS Final Report. Washington, DC: Population Council.

Munguti, Nzoya, Harriet Birungi, Rick Homan, Nicholas Mugumya, Juliana Nyombi, and Michael Matsiko. "Cost of training programs and willingness to pay for training: An application of break-even analysis in Uganda," FRONTIERS Final Report. Washington, DC: Population Council.

"Scaling up of quality assurance measure in district level management in Gujarat state," Asia and Near East OR Summary no. 15. Washington, DC: Population Council.

"Support for leadership and capacity building in Pakistan," Islamabad, Population Council.

\section{Transitions to Adulthood}

"Adolescents and youth in Pakistan 2001-02: A nationally representative survey," Data Sheet. Islambad, Population Council.

Amin, Sajeda, Judith Bruce, Erica Chong, Annabel Erulkar, Kelly Hallman, Barbara Mensch, and Jennefer Sebstad. "Using livelihoods initiatives to overcome adolescents' economic vulnerability and social isolation," Promoting Healthy, Safe, and Productive Transitions to Adulthood Brief no. 17. New York: Population Council.

Brady, Martha, Ragui Assaad, Barbara Ibrahim, Abeer Salem, Rania Salem, and Nadia Zibani.

“Providing new opportunities to adolescent girls in socially conservative settings: The Ishraq program in rural Upper Egypt," New York: Population Council.

Bruce, Judith and Erica Chong. "The diverse universe of adolescents, and the girls and boys left behind: A note on research, program and policy priorities," background paper to the report Public Choices, Private Decisions: Sexual and Reproductive Health and the Millennium Development Goals. New York: UN Millennium Project.

Erulkar, Annabel, Judith Bruce, Erica Chong, Aleke Dondo, Jennefer Sebstad, James Matheka, Arjmand B. Khan, and Anne Gathuku. "Tap and Reposition Youth (TRY): Providing social support, savings, and microcredit opportunities for young women in areas with high HIV prevalence," Promoting Healthy, Safe, and Productive Transitions to Adulthood Brief no. 15. Nairobi: Population Council.

Grant, Monica and Kelly Hallman. “Pregnancyrelated school dropout and prior school performance in South Africa," Policy Research Division Working Paper no. 212. New York: Population Council.

Hallman, Kelly, Sara Peracca, Jennifer Catino, and Marta Julia Ruiz. "Multiple disadvantages of Mayan females: The effects of gender, ethnicity, poverty, and residence on education in Guatemala," Policy Research Division Working Paper no. 211. New York: Population Council.

. "The multiple disadvantages of Mayan girls: The effects of gender, ethnicity, poverty, and residence on education in Guatemala," Promoting Healthy, Safe, and Productive Transitions to Adulthood Brief no. 16. New York: Population Council.

Lloyd, Cynthia B. “Schooling and adolescent reproductive behavior in developing countries," background paper to the report Public Choices, Private Decisions: Sexual and Reproductive Health and the Millennium Development Goals. New York: UN Millennium Project.

Santhya, K. G., Nicole Haberland, and Ajay K. Singh. "'She knew only when the garland was put around her neck': Findings from an exploratory study on early marriage in Rajasthan," New Delhi: Population Council.

Other

"Research that makes a difference: Selected resources" (updated June 2006), CD-ROM. New York: Population Councl. 


\section{(Population Council}

One Dag Hammarskjold Plaza, New York, NY 10017

Population Briefs is a research newsletter of the Population Council. The Council is an international, nonprofit, nongovernmental organization that

seeks to improve the well-being and reproductive health of current and future generations around the world and to help achieve a humane, equitable, and sustainable balance between people and resources. The Council conducts biomedical, social science, and public health research and helps build research capacities in developing countries. Established in 1952, the Council is governed by an international board of trustees. Its New York headquarters supports a global network of regional and country offices.

Writer/Editor: Gina Duclayan

Editorial Board: Cynthia B. Lloyd, Melissa May, Barbara A. Tokay, C. Johannes van Dam Production Manager: Y. Christina Tse Production Artist: Sura Rosenthal Copyeditor: Robert Heidel Editorial Assistant and Circulation: Debra Warn Population Briefs is distributed without charge. Information in this newsletter may be reproduced without permission, provided it is distributed without charge and the source is acknowledged. To receive e-mail when a new issue of Population Briefs is posted to the Population Council Web site, register at www.popcouncil.org/signup

ISSN 1084-6786

(C)2006 The Population Council, Inc.

\section{IN THIS ISSUE}

\section{POPULATION ASSESSMENT}

Children, in particular those who lost one or both parents, have been made especially vulnerable by the earthquake.

See page 1

\section{REPRODUCTIVE HEALTH}

Offering women with STIs the option of bringing medicines to their partners results in high treatment rates.
POVERTY, GENDER, AND YOUTH

"Mayan girls have by far the lowest primary school completion rates in Guatemala, due in large part to poverty-driven domestic labor burdens that begin to impinge upon them at puberty."

See page 3

\section{REPRODUCTIVE HEALTH}

"CDB-2914 may inhibit the growth of uterine fibroids, while not affecting the surrounding healthy smooth muscle." 